\title{
Ownership structure and corporate performance: empirical evidence of China's listed property companies
}

\author{
Qiulin Ke \\ Nottingham Trent University, School of Architecture, Design and the Built Environment, \\ Burton Street, Nottingham, NG1 4BU \\ David Isaac \\ University of Greenwich, School of Architecture and Construction, Avery Hill Campus, \\ Bexley Road, Eltham, London, SE9 2PQ
}

\begin{abstract}
This paper investigates the relationship of ownership structure and corporate performance of China's listed property companies. Data from all the listed property companies on China's stock market from 2000 to 2002 to study ownership concentration, type of controlling shares and their relation to corporate performance. The methodology applied is the conventional ordinary least square (OLS) model which is widely used in empirical studies on corporate governance. We find that ownership concentration has a positive association on corporate performance and the state shareholding is positively related to corporate performance; this is inconsistent with other empirical studies on the ownership structure and corporate performance of China's listed companies. This finding reflects the property industry's characteristics.
\end{abstract}

Keywords: ownership structure, state shares, legal person shares, corporate performance.

\section{Introduction}

The connection between ownership structure and performance has been the subject of an important and ongoing debate in corporate finance literature and has yielded mixed results. Theoretically, investors with large ownership stakes have a strong incentive to maximize the firm's value, are able to collect information and oversee managers and can assist in one of the principle- agent problems of the modern corporation - that of conflict of interest between shareholders and managers (Jensen and Meckling, 1977). At the same time, Shleifer and Vishny (1997, p. 758) point out, in terms of the entrenchment of large shareholders, that "large investors may respect their own interests, which need not coincide with the interests of other investors in the firm, or with the interests of employees and managers”. Empirically, Morck and Shleifer, and Vishny (1988) find an inverse U-shaped relationship between managerial equity ownership and firm valuation for a sample of U.S. firms. One interpretation is that the firm's performance improves with higher managerial ownership but that, after a point, managers become entrenched and pursue private benefits at the expense of outside investors.

Chinese stock market was opened in the early 1990s. By the end of 2002, there were 1200 companies listed on China's stock market and about 1.5 percent of the total population in China (about 20 million people) were active investors. Financing for companies from direct stock markets was about 10 percent of that from bank loans. 
Corporate governance is especially important in China as it is now facing transition from state-owned enterprise (SOE) to private-owned enterprise (POE). There is an increasing amount of empirical research addressed to the ownership structure of China's listed companies. Amongst these research papers is $\mathrm{Xu}$ and Wang (1999) who find that ownership concentration is positively related with firm performance. State shareholding and legal person shareholding (individual holdings) are respectively, negatively and positively related with firm performance. But, so far, few studies have been focused on any one specific industry. To bridge the gap, our studies focus on one industry sector, the property industry and use the data of China's listed property companies from 2000 to 2002. We follow the theory that ownership is relevant to firm performance and test the hypothesis that (1) ownership concentration is related to the corporate performance of listed property companies and (2) the type of controlling shareholder matters in corporate governance.

Property companies are amongst the ones listed earliest in China's stock market at the beginning of the 1990s. However, now, the initial public offer (IPO) of property company shares is under the strict control of government departments. By 2002, there were 50 listed companies that could be classified into the property sector based on the "Guideline of Industry Sector Classification for China's Listed Companies” issued by China's Securities Regulatory Commission (CSRC). In China, there are two types of property companies. One is the property development company which develops and then trades the property; their profits depending mainly on the trading of the property. Developing and then holding the property as an investment does not have a significant role in the activities of these property companies. The second type of property company is called the SEDZ type, that is property companies whose major businesses are carried on in the Special Economic Development Zones (SEDZ), and their activities include utilities construction, facilities building and managing, land renting, building, letting and managing the office buildings and industrial buildings within the SEDZ, etc. Most of these companies are local government offshoots, performing the task of building and administrating the Special Economic Development Zones.

The sample selection rule in this study is that each company should have at least two years or more consecutive fiscal years of financial statement data between 2000 and 2002. The two-year requirement represents an attempt to balance two sampling issues: collecting several observations for each company so that the econometric panel data technique can be used and limiting survivorship bias by allowing companies to enter and exit the panel over time. For the companies that were listed in 2002, we use the data of the previous year before listing on the stock market. For the one company that delisted from the stock market in 2001, its data is removed from the sample of 2000, as only one year's data was available.

In this paper we use the pooled data from the three years sample and employ the conventional ordinary least square (OLS) technique. The conventional least squaredummy-variable approach is also used in this paper in the pooled regressions, due to the characteristics of our data. This approach is widely used in the literature of ownership structure and corporate governance, and allows us to improve the efficiency of estimation 
without incurring heavy cost of technical complexity. In the other empirical studies (e.g. Morck et al, 1998; and Demsetz and Villalonga, 2001), the two-stage least square model (2SLS) is also used, since the authors argue that firms will adopt the appropriate governance mechanisms to control the agency problem (Jensen and Meckling, 1997, Demsets and Villalonga, 2001). However, this might not be the case in China's context during the study period, since the state shares and legal person shares have transfer restrictions and it is unlikely that the state, which has control over the majority of the listed companies, will sell its shares in poorly performing firms under the capital market environment in the study period. Therefore, the study variables in the sample may not be endogenous and the 2SLS model is not used here.

\section{Literature review}

The ownership structure around the world and the relationship of ownership structure to corporate performance are well documented among economists (e.g. Claessen, et al, 2002; Jensen and Meckling, 1976; Jensen, et al., 1983; Demsetz, 1983; Demsetz and Villalonga, 2001; Fama, 1980; Holderness and Sheehan, 1988; La Porta, 1999; Shleifer and Vishny, 1986 and 1997, etc.). These studies show that there is a striking variation in ownership structure internationally and the ownership structure is widely perceived to affect performance (Shleifer, 1998; Megginson and Netter, 2001). Much of the empirical research on ownership structure is based on the assumption of widely dispersed ownership structure and uses the data of U. S firms. Elsewhere, most firms are predominantly controlled by a single large shareholder (La Port et al 1999). In the Asian context, Claessens et al (2002) studied the relationship of ownership structure and firm's value of 1,301 publicly traded corporations in eight East Asian economies and found that the firm's value increases with the cash-flow ownership of the largest shareholder.

The studies in China's context include Bai and Wang, 1998; Chen and Xu, 2001; Chen and Jiang, 2000; Hu, 2000; Li, 1998; Tian, 2001; Sun and Tong, 2003; Xu and Wang, 1997. These studies investigate the relationship of ownership concentration, type of controlling share and their relationship to firm performance. For example, Sun and Huang (1999) find that Tobin's Q (Tobin's Q ratio: market values of liabilities divided by the minimum cost of replacing the assets that represent these liabilities) rises with the number of shares owned by the first large shareholder. Xu and Wang (1997) find that market-to-book ratio of listed companies is positively and significantly associated with the Herfindal index (i.e. the sum of squared ownership shares). The empirical studies by Chen and $\mathrm{Xu}$ (2001) show that in the industries where there is no government protection, the number of shares owned by the first large shareholder is positively associated with firm performance.

However, all these studies address all of the listed companies in China's stock market without differentiating the industrial characteristics. Sorensen (1999) argues that certain type of large block shareholders may have sufficient formal authority, social influence and expertise to capture property rights to gain control of the firm, giving them a disproportionately large amount of benefit and use rights. He suggests that a contingency 
theory of corporate governance where the effect of ownership on firm performance is contingent on the 'fit' between owner types and the industry contest. Therefore, based on this theory, we argue that certain types of controlling shareholders may have sufficient influence in China's property industry and lead to increased firm performance.

\section{Definition of study variables}

The data for the study were collected in the annual reports of the listed property companies published by China's Securities Regulatory Commission (CSRC). There were 37 companies in 2000, 50 in 2001 and 50 in 2002, making up 137 variables in all. The study variables are defined as follows:

- Top 10 (Top10): the number of shares owned by the top 10 large shareholders in the listed property companies as a measure of ownership concentration. This information is disclosed in the Annual Report of property companies. We expect a positive relationship between the top 10 ownership and firm performance.

- 1st large shareholder (1st holder): the number of shares owned by the first large shareholder of the company as a measure of the ownership concentration.

- 2nd large shareholder (2nd holder): the number of shares owned by the second large shareholder in the company as proxy of other block-holders.

- 3rd to 10th large shareholders (3rd -10th holders): the number of shares owned by the third to tenth large shareholders of the company as proxy of other blockholders.

- State-owned enterprise (SOE): an indicator variable. It equals one if the company is a state-owned company; otherwise it equals 0 .

- State-shares dominated company (ST-Sh. com): an in variable. It equals 1 if the company is dominated by state shares; otherwise it equals 0 if the company is dominated by legal person (individual) shares. State shares are held by the state and its varied ministries, bureaus and regional governments. State share is nontradable and the transfer of it is under the approval of China's Securities Regulatory Commission (CSRC).

- Fraction of state shares (ST-Sh.): the number of shares held by the state directly divided by the total number of shares outstanding.

- Fraction of legal person shares (LP-Sh.): the number of legal person shares (i.e. shares owned by any institution that has a legal person status such as an investment company) divided by the total number of shares outstanding. The legal person shares are restricted in transferability in market. The transfer of it is under the approval of CSRC.

- Fraction of tradable shares (TR-Sh.): the number of tradable shares divided by the total outstanding shares.

- Earning per share (EPS): profits after tax and interest divided by total outstanding shares. We use EPS as a measure of performance because the share capital of the listed property companies is fairly stable over the study period, thus it is a comparable measure.

- Return on assets (ROA): profit after tax and interest divided by the book value of total assets.

- Sales (Size): the total operating sales in billion of Yuan as a proxy of firm size.

- Debt to assets ratio (DAR): it equals the book value of the debt divided by the book value of assets.

- Growth rate: (Growth): this is measured by the annual growth of the sales. 


\section{Statistic tests and analysis}

\section{Descriptive statistics}

The measure of the ownership structure is based on the proportion of shares owned by firm's most significant shareholders. Table 1 displays the ownership concentration: percentage of shares owned by the Top 10 large shareholders from 2000 to 2002 and the correlation with number of shares owned by the 1st large shareholder of the property company. The concentration ratio measured by the number of shares owned by the Top 10 large shareholders is $\mathbf{5 6 . 4 9}$ per cent (median is $\mathbf{5 6 . 9 9}$ per cent) over three years.

The mean (median) of the 1st large shareholding is 41 per cent (40.01per cent), ranging from 0.39 per cent to 74.69 per cent. A difference exists across the firms. There is one company who has no controlling shareholder; the largest shareholding is 0.39 per cent and all the shares are tradable and widely dispersed. The mean (median) of the 2nd large shareholding is 7.25 per cent (5.75 per cent), ranging from 0.16 per cent to 23.78 per cent, whilst the other 8 large shareholdings (3rd to 10th) is, in total, 7.25 per cent (the median is 5.75 per cent). Obviously, the ownership structure indicates that many of the property companies have a single controlling shareholder.

The number of shares owned by the Top 10 large shareholders is positively correlated with the number of shares owned by the 1st large shareholder, and the numbers of shares owned by the 2nd and the other (3rd to 10th) block-holders are negatively associated with the 1st large shareholder. The 1st large shareholder is negatively correlated with legal person shares and tradable shares, but positively associated with state shares. All these suggest that the more the 1st large shareholder owns, the less the other block-holders own. In the state shares dominated companies, the ownership is more concentrated by the 1st large shareholder, be it the government agent, or the company itself.

Table 1 also reports the types of the shares held by the Top 10 large shareholders. The largest fraction is legal person shares with the mean of 29 per cent (median is 11.42 per cent), followed by state shares with the mean of 25.72 per cent (median is 11.99 per cent) and tradable shares with the mean of 1.25 per cent (median is 0.47 per cent). The tradable shares owned by the Top10 large shareholders are widely dispersed among institutional and individual investors. For example, in 2002, there are only 77 individual investors ranked amongst the Top10 large shareholders of all the 50 property companies, holding on average 0.2 per cent of the total outstanding shares per person. 0.2 per cent is a negligible figure compared with the controlling shareholder holding more than 40 per cent of total outstanding shares. It is conceivable that the dispersed individual ownership may give rise to the classic free-rider problem (Grossman and Hart, 1980) where small investors do not have the incentive or the capability to monitor managerial performance. Small shareholders' inactivity is further worsened by the block holdings of state shares and legal person shares which are restricted in transferability in the market. 
Table 1. Ownership concentration by Top 10 large shareholders and correlation with the first large shareholding (2000-2002)

\begin{tabular}{|l|l|l|l|l|l|l|l|}
\hline N=137 & Top 10 & $\begin{array}{l}1^{\text {st }} \\
\text { holder }\end{array}$ & $\begin{array}{l}2^{\text {nd }} \\
\text { holder }\end{array}$ & $\begin{array}{l}3^{\text {rd }}-10^{\text {th }} \\
\text { holders }\end{array}$ & LP-SH & ST-SH & TR-SH \\
\hline Mean & 56.49 & 41.1 & 7.25 & 8.13 & 29.04 & 25.72 & 1.25 \\
\hline Median & & & & & & & \\
\hline $\begin{array}{l}\text { Std. } \\
\text { Deviation }\end{array}$ & 16.1 & 17.82 & 6.15 & 7.43 & 25.79 & 27.87 & 2.43 \\
\hline Min. & 1.96 & 0.39 & 0.16 & 0.45 & 0 & 0 & 0 \\
\hline Max. & 78.88 & 74.69 & 23.87 & 37.28 & 74.28 & 74.69 & 13.68 \\
\hline $\begin{array}{l}\text { Corr.with } \\
1^{\text {st }} \text { holder }\end{array}$ & $0.75^{* *}$ & & $-0.29^{* *}$ & $-0.53^{* *}$ & $-0.32^{* *}$ & $0.75^{* *}$ & $-0.19^{*}$ \\
\hline
\end{tabular}

Table 2 reports the summary of the descriptive statistics of the other study variables. Over three years, the mean (median) EPS of the listed property companies is $0.1(0.15)$ and the mean (median) return on assets (ROA) is -1 per cent ( 3 per cent). The mean and median difference of ROA indicates the skewed distribution of firm performance and the relatively large negative figures have impact on the general performance. The mean (median) sales are $0.61(0.41)$ billion of Yuan and the average (median) growth rate is 49 per cent (14 per cent). 75 per cent of the listed property companies are state owned enterprises (SOEs), and 47 per cent of the listed property companies are dominated by state shares.

Table 2: Descriptive statistics of study variables of China's listed property companies from 2000 to 2002

\begin{tabular}{|l|l|l|l|l|l|l|l|}
\hline $\mathrm{N}=137$ & $\begin{array}{l}\text { EPS } \\
\text { (Yuan) }\end{array}$ & ROA & Size & Growth & DAR & SOE $^{\mathrm{a}}$ & $\begin{array}{l}\text { ST-SH } \\
\text { com }^{\mathrm{a}}\end{array}$ \\
\hline Mean & 0.1 & $-1 \%$ & 0.61 & $49 \%$ & $59 \%$ & $75 \%$ & $47 \%$ \\
\hline $\begin{array}{l}\text { Std. } \\
\text { Deviation }\end{array}$ & 0.53 & 0.34 & 0.77 & $2 \%$ & 0.4 & 0.43 & 0.5 \\
\hline Median & 0.15 & $3 \%$ & 0.41 & $14 \%$ & $54 \%$ & & \\
\hline Min. & -3.36 & $-377 \%$ & 0 & $-94 \%$ & $23 \%$ & & \\
\hline 1Max. & 1.2 & $37 \%$ & 4.57 & $1436 \%$ & $460 \%$ & & \\
\hline
\end{tabular}

Note: aFor the binary variables, the mean represents the proportion of firm which equals 1 for the variable.

\section{Regression tests}

We start by including as control variables several firm specific variables commonly used in the studies of firm performance. We include sales growth rate and the sales as proxy of firm size. We expect the firm size has positive effect on firm performance. We also use the variable of debt to assets ratio and expect it to be negatively related with firm performance.

Table 3 reports the outcomes of the regression. The second row displays the regression outcome of the control variables on EPS. The fourth row displays the regression outcome 
of the control variables on ROA. The Top10 is significantly different from zero in the regressions of EPS, and ROA and positively related to the corporate performance. This result is consistent with the previous empirical studies on the positive effects associated with the increased ownership in the hands of one or a few shareholders. The largest shareholder, no matter if it is the state or private institution, provides enough incentive to improve the asset efficiency of the company. Stiglitz (1985) has argued that one of the most important ways of value maximization by firms is through concentrated ownership of the firm's shares. La Porta et al. (1999) and Bebchuk (1999) suggest that in countries with poor investor protection, control should be concentrated to prevent an investor seizing it without paying the full price.

Table 3. Regression test of ownership structure and corporate performance from 2000 to 2002 (I)

\begin{tabular}{lllll} 
& EPS & ROA & EPS & ROA \\
\hline Sales & 0.20 & 0.06 & 0.20 & 0.06 \\
GROWTH & $(5.10)^{\star}$ & $(3.98)^{\star}$ & $(5.03)^{\star}$ & $(3.94)^{\star}$ \\
& 0.004 & 0.001 & 0.01 & -0.0004 \\
DAR & $(0.23)$ & $(0.09)$ & $(0.39)$ & $(-0.08)$ \\
& -0.69 & -0.76 & -0.67 & -0.77 \\
TOP10 & $(-8.93)^{\star}$ & $(-26.27)^{\star}$ & $(-8.67)^{\star}$ & $(-26.34)^{\star}$ \\
& 0.01 & 0.003 & & \\
1st holder & $(3.59)^{\star}$ & $(3.83)^{\star}$ & & \\
& & & 0.01 & 0.003 \\
2nd holder & & & $(3.22)^{\star}$ & $(2.96)^{\star}$ \\
& & & 0.004 & 0.01 \\
Others (3-10) & & & $(0.55)$ & $(2.71)^{\star *}$ \\
& & & 0.01 & -0.0002 \\
SOE & & & $(2.43)^{\star *}$ & $(-0.11)$ \\
& -0.02 & -0.02 & -0.01 & -0.02 \\
ST-SH. Com. & & $(-0.70)$ & $(-0.09)$ & $(-0.63)$ \\
& $(-0.19)$ & 0.002 & 0.03 & 0.01 \\
Adjusted R & 0.015 & $(0.09)$ & $(0.41)$ & $(0.22)$ \\
F & $(0.21)$ & 0.87 & 0.54 & 0.87 \\
Sig. & 0.54 & 148.88 & 20.54 & 113.05 \\
\hline & 27.17 & 0.00 & 0.00 & 0.00 \\
\hline
\end{tabular}

Note: (1): t-statistics are in parentheses.

$(2)^{\prime *}$ : represents significant at $0 \%$ level.

(3). ** represents significant at $5 \%$ level.

(4). ${ }^{* * * *}$ represents significant at $10 \%$ level.

SOE has no explanatory power in the equations of profitability ratios and yields mixed signs. Firm size has significant explanatory power, indicating the larger firms outperform the smaller ones, while the growth rate shows a positive but insignificant coefficient. The debt to assets ratio has negative impact on firm performance, as expected. Then, we have replaced the Top 10 with the ownership concentration ratios measured by the 1st large shareholder and other block-holders (2nd to 10th). To test the existence of free-rider problem, we have included the squared term of the number of shares owned by 2nd to 10th block-holders in the regression. The outcomes are reported in Table 4. 
The $1^{\text {st }}$ large shareholder is positively related with corporate performance and significant in the two equations. Chen and $\mathrm{Xu}$ (2001) suggest that in the non-protective industries in China, the number of the shares owned by the first large shareholder is positively related to corporate performance. The association of other block-holders to corporate performance is positive and significant in the equation of ROA, indicating other blockholders have enough incentive to monitor the management and maximize the firm value. As Table 1 shows that the majority number of shares owned by the other block-holders are owned by the second and third large shareholders of the companies, so this finding indicates that the presence of more than one controlling shareholders may improve the corporate governance of the property companies and corporate performance.

Bennedsen and Wolfenzon (2000) argue that the balance of the power in a closely held corporation is a mechanism to commit to lower levels of diversification. However, the relation is non-linear. The significant and negative association of the squared term of the other block-holders (2nd to 10th) in the two equations shows the existence of the freerider problem and the dispersed ownership structure may not be the best way to improve the economic efficiency of China's property sector. SOEs are negatively associated with firm performance, although insignificant. We can not say that all the SOEs are more inefficient than privately owned enterprises (POEs), since SOEs can be the ones controlled by state shares or state legal person shares. The positive, although insignificant, association of state shares dominated companies implies that the negative impact on SOEs as a whole may be caused by the SOEs dominated by legal person shares, but further investigation is required. Nevertheless, from the above statistical analysis, we cannot tell whether different types of controlling shares have effect on corporate performance. We, therefore, have separated the sample into two groups based on the type of controlling shares, one is dominated by legal person shares and the second group is dominated by state shares. We have run a series of regressions to test the effect of the different type of controlling shares on corporate performance. Table 4 reports the outcomes of the regression.

Table 4: Regression of ownership structure and corporate performance of China's listed property companies from 2000 to 2002 (II)

\begin{tabular}{|c|c|c|c|c|c|c|c|c|c|}
\hline & Size & Growth & DAR & Top10 & LP-SH & SOE & Adjusted $\mathrm{R}^{2}$ & $\mathrm{~F}$ & P-value \\
\hline \multicolumn{10}{|c|}{ Legal person shares dominated $(\mathrm{N}=71)$} \\
\hline EPS & $\begin{array}{c}0.3 \\
(2.01)^{\star \star}\end{array}$ & $\begin{array}{c}-0.02 \\
(0.60)\end{array}$ & $\begin{array}{c}-0.77 \\
(6.32)^{\star \star \star}\end{array}$ & $\begin{array}{c}0.02 \\
(1.77)^{\star}\end{array}$ & $\begin{array}{c}-0.02 \\
(-1.47)\end{array}$ & $\begin{array}{c}0.03 \\
(0.27)\end{array}$ & 0.51 & 11.54 & 0 \\
\hline ROA & $\begin{array}{c}0.07 \\
(1.28)\end{array}$ & $\begin{array}{l}-0.01 \\
(-0.79)\end{array}$ & $\begin{array}{c}-0.77 \\
(16.57)^{\star \star \star}\end{array}$ & $\begin{array}{c}0.01 \\
(2.39)^{\star *}\end{array}$ & $\begin{array}{c}-0.01 \\
(-2.27)^{\star \star}\end{array}$ & $\begin{array}{c}-0.01 \\
(- \\
0.25)\end{array}$ & 0.85 & 61.04 & 0 \\
\hline & Size & Growth & DAR & Top10 & ST-SH & & AdjustedR $^{2}$ & $\mathrm{~F}$ & P-value \\
\hline \multicolumn{10}{|c|}{ State share dominated $(\mathrm{N}=64)$} \\
\hline EPS & $\begin{array}{c}0.24 \\
(3.89)^{\star \star \star}\end{array}$ & $\begin{array}{c}0.03 \\
(1.30)\end{array}$ & $\begin{array}{c}-0.54 \\
(-2.55)^{\star \star}\end{array}$ & $\begin{array}{l}0.004 \\
(0.72)\end{array}$ & $\begin{array}{c}0 \\
(0.33)\end{array}$ & & 0.24 & 4.37 & \\
\hline ROA & $\begin{array}{c}0.03 \\
(2.43)^{\star \star}\end{array}$ & $\begin{array}{c}0 \\
(0.74)\end{array}$ & $\begin{array}{c}-0.18 \\
(4.50)^{\star \star}\end{array}$ & $\begin{array}{c}-0.0003 \\
(-0.31)\end{array}$ & $\begin{array}{c}0 \\
(1.41)\end{array}$ & & 0.25 & 4.46 & \\
\hline
\end{tabular}

Note: (1): t-statistics are in parentheses.

$(2)^{* *}, * *, * * *$ represent significant at 10per cent, 5per cent and 1per cent levels. 
For the legal person shares dominated property companies, the ownership concentration measured by the Top10 is positively associated with the performance ratios and significant in the two equations of EPS and ROA. But the legal person shares are negatively correlated with the performance ratios and significant in the equation of ROA at $5 \%$ level. Since the legal person shares dominated companies can be SOEs or POEs, the test doesn't show the negative impact is caused by SOEs dominated by legal person shares or POEs. SOE has no explanatory power in the fi rm performance in this group.

In the state shares dominated companies, the ownership concentration measured by the Top10 has no explanatory power to the corporate performance in both of the equations of EPS and ROA. The state shares have positive impact on the corporate performance but insignificant. This finding is inconsistent with the studies by Xu and Wang (1997) who suggest that the state shares have a negative but insignificant effect on corporate performance, while legal person shares have a positive but significant effect on the corporate performance. However, Tian (2001) argues that the corporate performance increases with the state shareholding when the government is a large shareholder. China's property industry is subject to the influence of the government's preferential policy and macro economic adjustments. The land market is not completely transparent and is controlled by the government. Although the property industry is not monopolized by the government, the government has significant influence on property industry. The findings here seem to suggest that the state owned property companies, larger in size, are more likely to achieve government support. As argued by Chen and Jiang (2000), a certain type of shareholder cannot be believed to have positive influence on the corporate governance in all the industries of China and the positive influence of the diversified ownership structure depends on market competition within the industry.

\section{Conclusions}

There has been much research concerning the relationship between ownership structure and firm performance in China's corporate governance context. But research in a specific industry sector is rare. Our study focuses on the property industry sector and aims to provide supplementary evidence to the literature of the impact of ownership structure on firm performance in China's context.

In China, where the legal protection of minority share holders is weak, ownership concentration is beneficial to corporate performance. Types of controlling shares are relevant to corporate performance. In the property sector, state shares have significant influence on the corporate performance. State shares controlled companies are larger in size and have a more concentrated ownership measured by the 1st large shareholding. They are more likely to gain the government's preferential policy and support, therefore the state has an important influence on the corporate performance of these property companies. These are the characteristics of the industry sector under the current market environment.

Although these findings support the other empirical suggestion that large shareholders have enough incentives to maximize the value of the firm, in China, due to the special 
ownership structure of listed companies, the state shareholding is the largest holding, but the representatives of the state shareholding are usually government politicians who have ownership rights in the company but no claim rights for the residual value of the company. In this case, these politicians have no incentive to monitor the performance of management and in practice, the owner of the company is absent and the company is controlled by the insider (so called insider control). This reduces the restrictions on management and the managers could pursue consumption at the expense of the investment value of the company. The breakdown of the sole control of the single shareholder and the presence of the other block-holders may enhance the supervision and monitoring of the management and improve the corporate governance.

In other empirical studies on the association of types of controlling shares to corporate performance of China's listed companies, the legal person shares are treated as one group without distinguishing the ultimate owners - state versus non-state. The conclusion drawn from these studies may not be applicable to property companies amongst which $25 \%$ of them are non-state owned companies.

Since the second half of 2004, the Chinese government has started to launch the reform of the corporate ownership structure to enhance the corporate governance, introduce modern management incentives and open market competition mechanisms into corporations and attract the international investors. The state shares were to be transferred to institutions gradually. This research on ownership structure provides supplementary evidence for the reforms.

\section{References}

Bai, C. and Wang, Y. (1998) Bureaucratic control and the soft budget constraint Journal of Comparative Economics, 26(1), 41-46.

Bebchuk, L.A. (1999) A rent-protection theory of corporate ownership and control. NBER working paper, No. 7203.

Bennedsen, M. and Wolfenzon, D. (2000) The balance of power in closely held corporations, Journal of Financial Economics, 58, 113-139.

Chen X. Y. and Xu X. D. (2001) Ownership structure, firm performance and investors protection. Economic Research Journal, 11 (Nov), 3-11.

Chen, X. and Jiang D. (2000) The diversified owner ship, corporate performance and industry competition. Journal of Economic Research, 8 (Aug), 28-35.

China Securities Regulatory Commission (2003) China's Securities and Futures Statistical Yearbook 2003, Baijia Publishing House.

Claessens, S., Djankov, S. and Lang, L. (2002) Disentangling the incentive and entrenchment effects of large shareholdings. Journal of Finance, 57(6), 2741-2771.

Demsetz, H. and Villalonga, B. (2001) Ownership structure and corporate performance. Journal of Corporate Finance, 7(3), 209-233.

Fama, E.F. (1980) Agency problems and theory of the firm. Journal of Political Economy 88, 288-307.

Grossman, S. and Hart. O. (1980) Takeover Bids, the Free-Rider Problem, and the Theory of the Corporation. Bell Journal of Economics, 11, 42-64. 
Holderness, C. and, Sheehan, D. (1988) The role of majority shareholders in publicly held corporations: An exploratory analysis. Journal of Financial Economics 20, 317-346. $\mathrm{Hu}, \mathrm{R}, \mathrm{R}$. (2002) Class action: practice in China, the Fourth Meeting of the Asian Roundtable. 11-13 November, Mumbai, India

Jensen, M. C. and Ruback, R. S. (1983) The market for corporate control: the scientific evidence. Journal of Financial Economics 11, 5-50.

Jensen, M. C. and Meckling, W. H. (1977) Theory of the firm: managerial behaviour, agency costs and ownership structure. Journal of Financial Economics 3, 305-360.

La Porta, R., Lopez-de-Silanes, F. and Shleifer, A. (1999) Corporate ownership around the world. Journal of Finance 54, 1115-1155.

Li, D. D. (1998) A theory of ambiguous property rights: the case of the Chinese non-state sector. Journal of Comparative Economics, 23(1), 1 - 19.

Megginson, W. L. and Netter, J. M. (2001) From state to market: a survey of empirical studies on privatization. Journal of Economic Literature, 39(2), 321-389.

Morck, R., Shleifer, A. and Vishny, R. (1988) Management ownership and market valuation: an empirical analysis. Journal of Financial Economics 20, 293-316.

Morck, R., Shleifer, A. and Vishny, R. (1988) Management ownership and market valuation: an empirical analysis. Journal of Financial Economics 20, 293.

Shleifer, A. and Vishny, R. (1986) Large shareholders and corporate control. Journal of Financial Economics 5, 309-327.

Shleifer, A. and Vishny, R. (1998) A survey of corporate governance. Journal of Finance 52, 737-783.

Shome, D. and Singh, S. (1995) Firm value and external block-holdings. Financial Management 24, 3-14.

Sorensen, A. B. (1999) Ownership organization and firm performance. Annual Review of Sociology. 25, 121-144.

Stiglitz, J.E. (1985) Credit markets and the control of capital. Journal of Money, Credit and Banking. 17(2) 133-152.

Sun, Q. and Tong, W. (2003) China share issue privatization: the extent of its success, Journal of Financial Economic, 70, 182-222.

Sun, Y. X. and Huang, Z. H. (1999) The ownership structure and performance of listed companies, Economic Research Journal, 12 (Dec), 23-31.

Tian, G. (2001) State shareholding and the value of China's firms. LSE , William Davidson Working Paper. 395, April.

Xu, X. N. and Wang, Y. (1997) Ownership Structure, Corporate Governance and Firms' Performance: the Case of Chinese Stock Companies, World Bank Washington, DC. 